\title{
In vitro REGENERATION OF Didymopanax morototoni
}

\author{
FRANCO, E. T. H. ${ }^{1}$, GAVIOLI, L. B. ${ }^{1}$ and FERREIRA, A. G. ${ }^{2}$ \\ ${ }^{1}$ Departamento de Biologia, Universidade Federal de Santa Maria, Santa Maria, RS, Brazil \\ ${ }^{2}$ Departamento de Botanica, IB, Universidade Federal do Rio Grande do Sul, \\ CEP 91509-970, Porto Alegre, RS, Brazil \\ Correspondence to: Alfredo Gui Ferreira, Departamento de Botanica, IB, Universidade Federal do Rio Grande do Sul, \\ C. P. 15015, CEP 91509-970, Porto Alegre, RS, Brazil, e-mail: ferreira@ pesquisador.cnpq.br \\ Received March 5, 2004 - Accepted May 3, 2004 - Distributed May 31, 2006
}

(With 7 figures)

\begin{abstract}
The present study aimed at establishing a complete plant regeneration protocol for Didymopanax morototoni (matchwood), a native Brazilian forest species. Four types of explants (root, shoot, node, and cotyledonary leaves) were obtained from in vitro germinated seeds. In the first step, woody plant medium (WPM) with casein hydrolysate $\left(250 \mathrm{mgL}^{-1}\right)$ and 2,4-D $\left(1.0\right.$ and $\left.5.0 \mathrm{mgL}^{-1}\right)$ were used combined with kinetin $\left(0.1\right.$ and $\left.1.0 \mathrm{mgL}^{-1}\right)$. Twenty days after inoculation, the material was evaluated. Embryogenic calli were split, transferred to expression medium with several combinations of NAA and KIN, and moved to fresh medium after 60 days. Light did not interfere in embryo expression. Somatic embryos were formed either from individual cells or cell clusters. Plantlets were obtained in WPM medium and $10 \mathrm{gL}^{-1}$ of sucrose with no plant regulator, or using $0.1 \mathrm{mgL}^{-1} \mathrm{BAP}$ and $0.5 \mathrm{mgL}^{-1} \mathrm{GA}$. Plantlets from somatic embryos of D. morototoni developed in $33 \%$ of the cases.
\end{abstract}

Keywords: somatic embryo, woody plants, embryogenesis, plantlets, Schefflera (Didymopanax), Araliaceae.

\section{RESUMO}

\section{Regeneração in vitro de Didymopanax morototoni}

O presente estudo visou o estabelecimento de um completo protocolo de regeneração para Didymopanax morototoni (morototó, caixeta) uma espécie florestal nativa do Brasil. Quatro tipos de explantes (raiz, caule, nódulo foliar e folha cotiledonar) foram obtidos a partir de sementes germinadas. Na primeira etapa, meio WPM com caseína hidrolisada $\left(250 \mathrm{mgL}^{-1}\right)$ e $2,4 \mathrm{D}\left(1,0\right.$ e 5,0 $\left.\mathrm{mgL}^{-1}\right)$ foram usados em combinação com cinetina $\left(0,1\right.$ ou $\left.1,0 \mathrm{mg} \mathrm{L}^{-1}\right)$. Vinte dias depois de inoculado, o material foi avaliado. Calos embriogênicos foram divididos e transferidos para meio de expressão com várias combinações de ácido naftaleno-acético e cinetina, e repicados a cada 60 dias para meio novo. A luz não interferiu na expressão embriogênica. Embriões somáticos foram formados ou de células individuais ou de agregados de células. As plântulas foram obtidas no meio WPM com $10 \mathrm{~g} \mathrm{~L}^{-1}$ de sacarose e sem reguladores de crescimento ou com $0,1 \mathrm{mg} \mathrm{L}^{-1}$ de Benzil-adenina e $0,5 \mathrm{mg} \mathrm{L}^{-1}$ de giberelina. O desenvolvimento das plântulas a partir de embriões somáticos de D. morototoni foi alcançada em $33 \%$ dos casos.

Palavras-chave: embrião somático, plantas lenhosas, embriogênese, Schefflera (Didymopanax), Araliaceae.

\section{INTRODUCTION}

Didymopanax morototoni (Aublet) Decaisne et Planchon, known in Brazil as morototó or caixeta is potentially important as a reforestation species (Daniel et al., 1994). Besides fast growth, it offers several characteristics recommending its use in mass culture such as straight cylindrical trunks, sought after as timber and by craftworkers.

In spite of its plentiful fruit production, seeds do not germinate easily, and the species itself is 
somewhatrare in natural formations. The conventional methods of propagation by cutting stocks and grafting sections are difficult and not very often successful, thus limiting nursery plant production and, consequently, supply for reforestation programs. However, micropropagation of this species has been done (Mantovani et al., 1999).

Somatic embryogenesis is another useful technique since large quantities of plants can be produced in limited spaces at relatively low cost (Gratapaglia \& Machado, 1999). But micrografting in the rooting stage of woody plants is a possible obstacle.

Somatic embryo development can take place either directly (without intervening calli), or indirectly (with an initial callus phase). The presence of competent cells, which is basically expressed by the physiological state (De Jong et al., 1993) may be the beginning of somatic embryo development (Raemakers et al., 1995). Thus, cells detached from surrounding areas could be stimulated to begin embryogenesis pathway, and the presence of plant growth regulators could change cell sensitivity and differentiation (Trewavas, 1991; Guerra \& Handro, 1998).

For successful in vitro somatic embryogenesis, selecting the right explant is crucial, and in the case of some species has been enough to obtain somatic embryos (Ammirato, 1983). But in some species almost all tissue is responsive, e.g., tobacco, carrot, and potato, whereas in others, only embryonic tissue is (Bajaj, 1995). Furthermore, according to Haccius (1978), somatic embryos can begin from a meristematic cell layer. In any case, explant origins can be revealed by histological studies at various developmental stages of somatic embryogenesis (Canhoto \& Cruz, 1996). In any case, explant origins can be revealed by histological studies at various developmental stages of somatic embryogenesis.

There are several formulations for in vitro culture, among which woody plant medium (WPM) (Lloyd \& McCown, 1980) and liquid proliferation medium (LPm) (Von Arnold \& Eriksson, 1981) are widely used. Microcuttings of $D$. morototoni have been grown when using WPM (Mantovani \& Franco, 2000).

Plant regeneration via somatic embryogenesis may be considered successful when complete plantlets are produced and adequately acclimatized to ex-vitro conditions.
The purpose of this investigation was to: a) determine the most suitable explant of D. morototoni for somatic embryogenesis; b) develop a protocol for somatic embryogenesis in this species; c) establish the histological origin of somatic embryos; and d) regenerate complete plantlets acclimated to ex-vitro conditions.

\section{MATERIALS AND METHODS}

Seeds of Didymopanax mortotoni (Aubl.) Dcne \& Planch (= Schefflera morototoni (Aubl.) Macguire, Steyerm. \& Frodin) were collected on the ground under the canopies of several trees in the central part of Rio Grande do Sul state, Brazil. They were disinfected and germinated in vitro (Franco \& Ferreira, 2002). Explant sources were fifty-day-old seedlings split into root, stem, stem node, and blade.

The explants were cultured for twenty days in WPM (Lloyd and McCown, 1980) solidified in $0.65(\% \mathrm{w} / \mathrm{v})$ agar medium (Difco-Bacto), supplemented with $250 \mathrm{mgL}^{-1}$ casein hydrolysate and $30 \mathrm{gL}^{-1}$ sucrose. The medium was autoclaved and immediately thereafter, 1 or $5 \mathrm{mgL}^{-1} 2,4$ filtersterilized dichlorophenoxyacetic acid (2,4-D) and 0.1 or $1.0 \mathrm{mgL}^{-1}$ kynetin (Kin) were added. The calluses obtained were uniformly split and cultured in the same medium to which had been added $0 ., 0.01,0.1$, and $1.0 \mathrm{mgL}^{-1}$ naphthalaneacetic acid (NAA) and $0 ., 0.01,0.1, \quad 1.0$, and $10.0 \mathrm{mgL}^{-1}$ kinetin. The material was cultured in a growth room either at $14.3 \mu \mathrm{Em}^{-2} . \mathrm{s}^{-1}$ PPFD for a $16 \mathrm{~h}$ light photoperiod or in darkness at $25 \pm 2{ }^{\circ} \mathrm{C}$. All experiments were arranged in a randomized layout with 10 replications.

To obtain complete plant regeneration, four somatic embryos/petri plate of similar size and weight and at the same developmental stage were placed in $1 / 2$ WPM or full strengh WPM, plus sucrose 10,20 , and $30 \mathrm{gL}^{-1}$ and $1.5 \mathrm{gL}^{-1}$ of activated charcoal. Agar and hydrolysated casein were used as previously described for somatic embryogenesis. No phytoregulators were used in this period. Growth, rooting, and multiplication rates were recorded after 60 days. Number of leaves, and root and shoot length were also noted. Each treatment was replicated ten times.

For histological studies the explants were fixed in $3 \%$ glutaldehyde in a $0.1 \mathrm{M}$ phosphate 
buffer, pH 7.2, for $24 \mathrm{~h}$ (Gabriel, 1984). Dehydration was obtained through standard ethanol series ( $1 \mathrm{~h}$ per step). The samples were preembedded in hydroximethylmetacrilate and ethanol (1:1), followed by infiltration (Jung's hystoresin). For general examination, semi-thin (3-5 $\mu \mathrm{m})$ sections were cut on a 781 ANCAP mycrotome and stained with $0.2 \%$ toluidine blue buffered at pH 4.0 (O’Brien \& McCully, 1981).

The experimental design was completely randomized with ten replicates per treatment. Data were subjected to analysis of variance; means were compared by Duncan's test $(\mathrm{p} \leq 0.01)$

\section{RESULTS}

Explants from root, stems, cotyledonary leaves, and leaf nodes of fifty-day-old seedlings generated calli after cultured for 20 days in the presence of growth regulators. Calli were (color) white to green, (texture) compact to friable, and (surface) smooth to rough. Callus induction in darkness was more efficient than that in light (Figs. 1a and 1b). Leaves and nodes were the most responsive explants in this phase.

Sixty percent of the embryos were induced in the treatment with $5.0 \mathrm{mgL}^{-1} 2,4-\mathrm{D}$ plus $0.1 \mathrm{mgL}^{-1}$ Kin. Five $\mathrm{mgL}^{-1}$ 2,4-D plus $1.0 \mathrm{mgL}^{-1}$ Kin yielded $20 \%$ of the embryos; another $20 \%$ were obtained by adding $1.0 \mathrm{mgL}^{-1} 2,4-\mathrm{D}$ plus $1.0 \mathrm{mgL}^{-1} \mathrm{Kin}$.

When these calli were split and cultured for 4 months in the presence of NAA and Kin more calli tissue was produced. Low phytoregulator concentrations applied to calli derived from shoot and leaf node sources were the most efficient combinations, producing friable, yellowish embryogenic calli. These were most apt to produce embryos (Figs. 2a and b), although more compact,
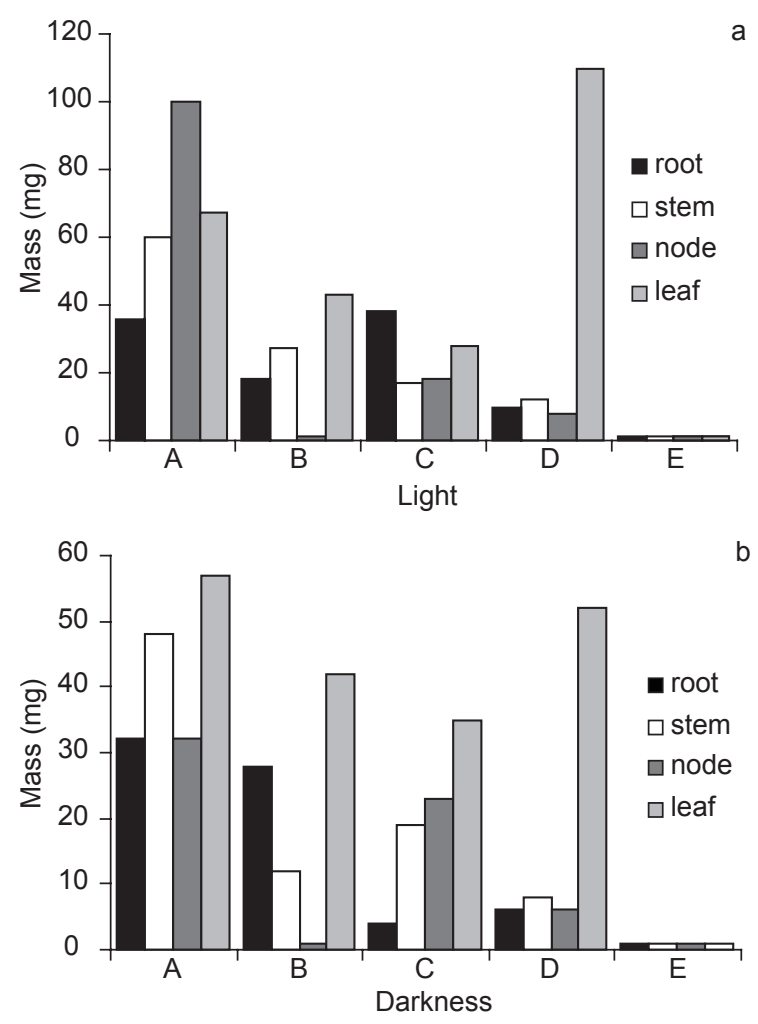

Fig. 1 - Dark-grown (a) and light-brown (b) callus weight induced by 2,4 dichlorophenoxyacetic acid (2,4-D) and kinetin (Kin) from root, shoot, and cotyledonary leaves and node leaves of Didymopanax morototoni. $\mathrm{A}=1.0 \mathrm{mgL}^{-1} 2,4-\mathrm{D}+$ $0.1 \mathrm{mgL}^{-1} \mathrm{Kin} ; \mathrm{B}=1.0 \mathrm{mgL}^{-1} 2,4 \mathrm{D}+1.0 \mathrm{mgL}^{-1} \mathrm{Kin} ; \mathrm{C}=5.0 \mathrm{mgL}^{-1} 2,4-\mathrm{D}+0.1 \mathrm{mgL}^{-1} \mathrm{Kin} ; \mathrm{D}=5.0 \mathrm{mgL}^{-1} 2,4-\mathrm{D}+1.0 \mathrm{mgL}^{-1}$ Kin; and $\mathrm{E}=$ control (no plant growth regulator). 

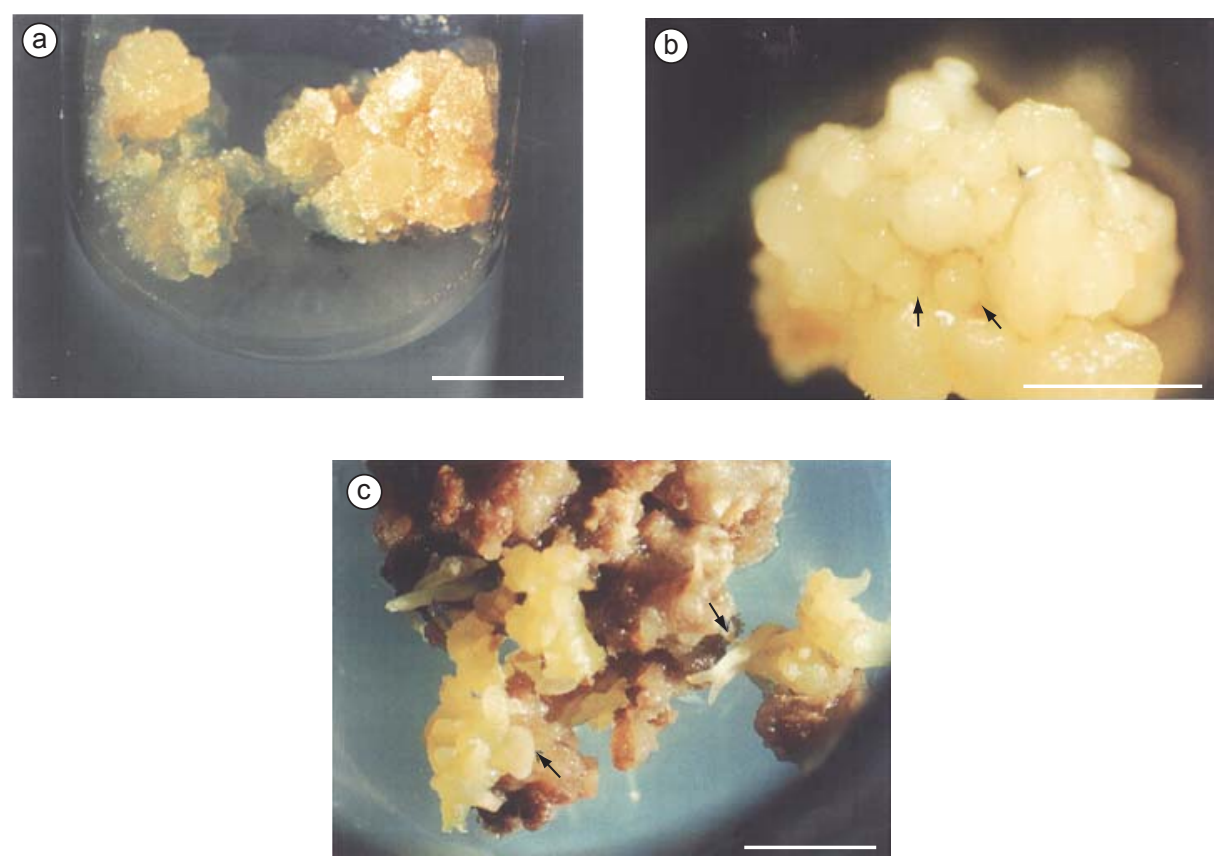

Fig. 2 - D. morototoni callus morphology. a: Non-uniform light-cultivated callus with greenish compact zones and more friable, granular, and yellowish parts; b: Cluster of embryos at globular stage; and c: Friable calli covered by embryos at several developmental stages. The arrow indicates an embryo at cotyledonary stage. $\mathrm{Bar}=1 \mathrm{~cm}$.

greenish calli were also capable of embryo production (Fig. 2c)

No embryos were produced directly, except those derived from or adjacent to cambial tissue and pericycles (Fig. 3a). Centers of competent cells had been observed in a few compact calluses (Fig. 3b), but usually friable calli (Fig. 3c) gave rise to an indefinite number of embryos (Fig. 3d).

There was a conversion to plantlets of somatic embryos, demonstrating their physiological and morphological maturity (Fig. 4a). Plantlet survival in pots was around $33 \%$, which can be considered reasonable (Fig. 4b).

Plantlet size (Fig. 5a), root numbers (Fig. 5b), and leaf number (Fig. 5c) were lower at highest concentration of plant growth regulators (BAP and $\mathrm{GA}_{3}$ ) used. The results for the control without plant growth regulators did not differ from those for the lowest concentration of plant growth regulators.

The rooting and multiplication rates were significantly higher when full-strength WPM medium was used (Fig. 6). Sucrose reduction increased leaf number but did not affect root and shoot length (Fig. 7).

\section{DISCUSSION}

Since young tissues have higher meristematic activity, higher surviving rate and better in vitro growth (Litz \& Jarret, 1991; Tisserat et al., 1979), they are used in converting somatic cells into embryogenic cells. This process begins with an induction phase, followed by the expression phase, in which competent cells are triggered by various factors. Cells in different differentiation stages and determination degrees are, mediated by phytoregulators, able to acquire competence (Sharp et al., 1980; Christianson \& Warnick, 1988). According to Vasil (1982), embryonic competence induction occurs in the presence of high auxin concentration, the most commonly used being 2,4-D (Jimenez, 2001; Mathur et al., 2001). However, morphogenic structure expression should occur in the absence, or at lower auxin levels. If 2,4-D is replaced by a weaker auxin such as NAA in a relatively low concentration (between 0.1 and $0.01 \mathrm{mgL}^{-1}$ ), somatic embryo expression is possible. For D. morototoni, kinetin applied at the same low concentration as NAA, appears to benefit the expression phase. The substitution of 2,4-D by 

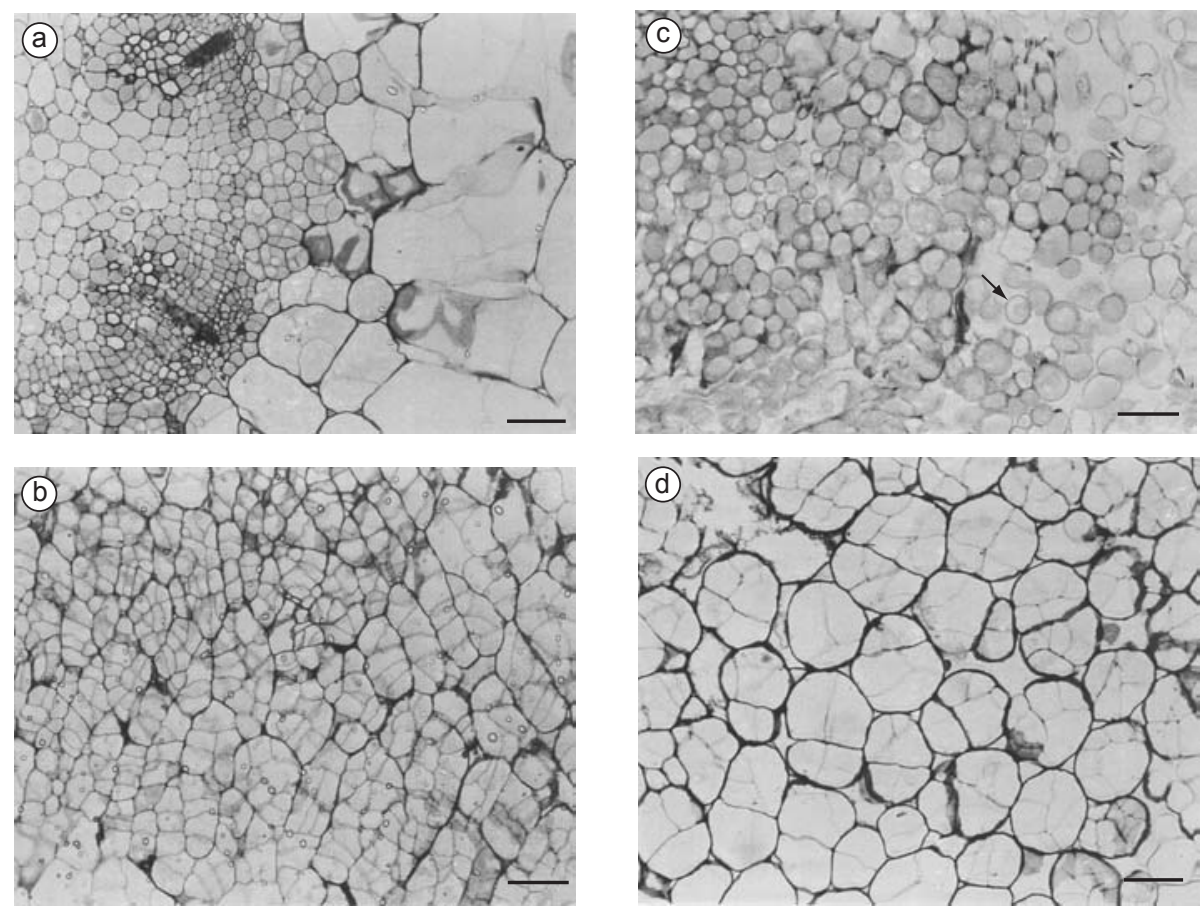

Fig. 3 - Histological section of D. morototoni explants. a) Cotyledonary node explant showing a sprout of cells with dense cytoplasm and thick walls; arrow indicates an early globular embryo near the pericycle; b) Section through a dense callus, showing cells with thick walls, a typical somatic embryo precursor; c) Sectioned friable, typically embryogenic callus; and d: Group of cells with thick walls in a pre-globular stage in embryos originating in parenchyma tissue. Bar $=60 \mu \mathrm{m}$.
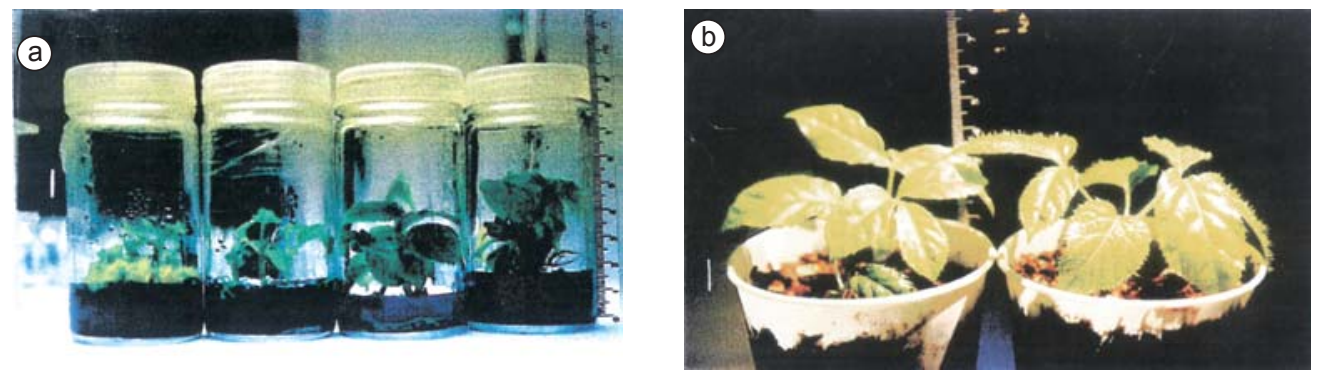

Fig. 4 - a) D. morototoni plantlets in axenic conditions just before transferal to ex-vitro conditions; and b) Potted plantlets (scale $\mathrm{cm})$.

NAA in the second step furthered expression in several other species, e.g., Olea europea (ShibliRida et al., 2001), Simmondsia chinensis (Hamama et al., 2001), and Quercus robur (Zegzouti et al., 2001)

Histological study of the D. morototoni explants indicates that somatic embryos may begin in two ways: 1) in the pericycle layer; and 2) in parenchymal cells of the explant callus. In the first case, embryos seem to originate from either a single cell or a few competent cells, whereas those developed from calli appear to have a multicelular origin. These observations differ from those made by Canhoto \& Cruz (1996). But embryo origin is difficult to determine exactly (Faure et al., 1996), in spite of the numerous anatomical slices analyzed. In any case, a dual origin has been already been suggested for somatic embryos (Barciela \& Vieitz, 1993; Puigderrojols et al., 2001; Williams \& Maheswaran, 1986). 

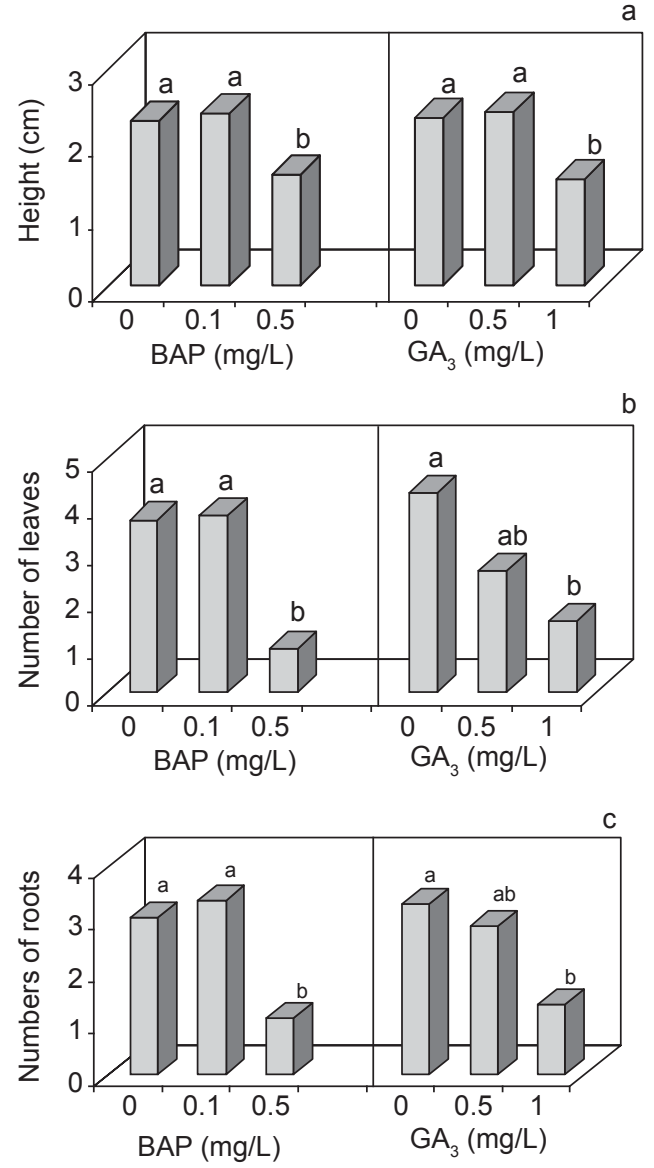

Fig. 5 - Effects of BAP and $\mathrm{GA}_{3}$ concentrations on height of D. morototoni plantlets derived from somatic embryos; b) Effect of $\mathrm{BAP}$ and $\mathrm{GA}_{3}$ concentrations on the average number of roots/plantlet of D. morototoni; and c) Effect of BAP and $\mathrm{GA}_{3}$ concentrations on the number of leaves/plantlet. The same letter within the same parameter does not differ statistically by Duncan's test ( $\mathrm{p} \leq 0.01)$.

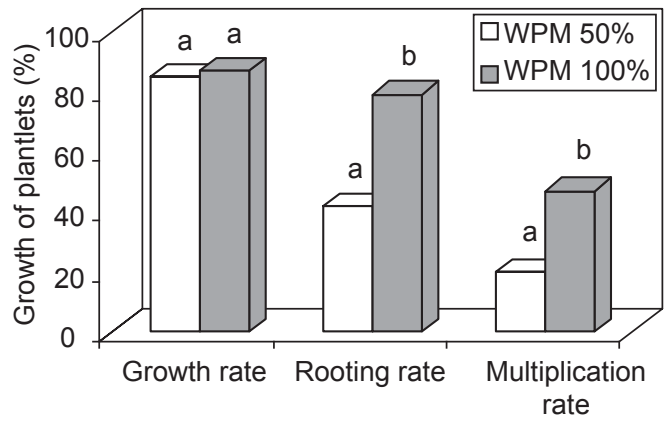

Fig. 6- Growth, rooting. and multiplication rates of D. morototoni plantlets in $1 / 2$ WPM and full-strength WPM medium. The same letter within the same parameter does not differ statistically by Duncan's test $(\mathrm{p} \leq 0.01)$.

Embryogenic cells were minute, resembled meristematic cells, displayed more densely staining nuclei and nucleoli, denser cytoplasm and starch grains, and a thick cell wall. Such walls are characteristic of somatic embryo formation (Canhoto \& Cruz, 1996; Canhoto et al., 1999; 


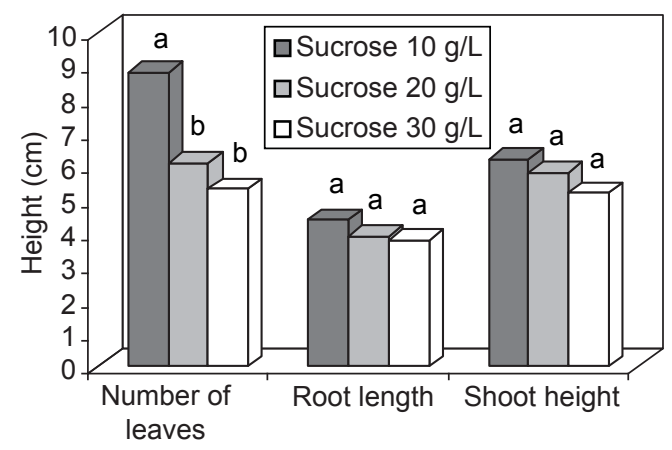

Fig. 7 - Evaluation of D. morototoni growth after 60 days of culture in three sucrose concentrations. Root lengths and shoot heights in centimeters. The same letter within the same parameter does not differ statistically by Duncan's test $(\mathrm{p} \leq 0.01)$.

Verdeil et al., 2001), which is quite clear in Fig. 3b, $3 \mathrm{~d}$.

Of the four kinds of explants tested, only the shoot and nodal segments allowed somatic embryo induction and development. This is critical, in some species, for explants that in spite of friable calli, root and leaf explants do not complete embryogenesis, and for other species might be due to not only to physiological differences among explant sources, but also to conditions under which development took place (Harry \& Thorpe, 1991; Jimenez, 2001). Cytokinin presence can stimulate somatic embryo maturation (Evans et al., 1981) and make plantlet regeneration feasible, as was the case for Myrtus comunis (Canhoto et al., 1999). But absence of plant growth regulators generally yielded better developmental responses for Eucalyptus (Muralidharam \& Mascarenhas, 1995), Juglans cinerea (Pijut, 1993), and Simarouba glauca (Rout \& Das, 1994). Addition of plant growth regulators should not be recommended for $D$. morototoni after the conversion stage.

Sucrose increase in the medium may have inhibited carbon metabolism and chlorophyll amount, and reduced the activity of D-ribulose1-5-biphosphate carboxylase/oxygenase and, consequenly, carbon uptake. Hdider \& Desjardins (1994) demonstrated that strawberry plants grown at $0.1 \%$ sucrose had a higher photosynthesis rate, hence were more autotrophic. For D. morototoni sucrose decrease produced more vigorous plantlets.

Through the procedure outlined here, a degree of success was reached for D. morototoni comparable to that obtained for Panax ginseng, another Araliaceae (Mathur et al., 2001).
Acknowledgments - The authors would like to thank Dr. A .G. Fett-Neto for a critical review of the manuscript, and B. Cassol for help with the photographs. This work, part of a Ph.D. dissertation of the first author, was supported by Fundação de Amparo à Pesquisa do Estado do Rio Grande do Sul (FAPERGS-proc. 96/1568-6). A. G. F. is grateful to the Brazilian Research Council (CNPq) for granting a fellowship (Proc. 350038/97-0).

\section{REFERENCES}

AMMIRATO, P. V., 1983, Embryogenesis, pp. 82-123. In: D. A. Evans, W. R. Sharp, P. V. Ammirato \& Y. Yamada (Eds.) Handbook of plant cell culture, MacMillan, New York.

BAJAJ, Y. P. S., 1995, Somatic embryogenesis and its applications for crop improvement, pp. 105-119. In: Y. P. S. Bajaj (ed) Biotechnology in agriculture and forestry 30: somatic embryogenesis and synthetic seed I SpringerVerlag, New York.

BARCIELA, J. \& VIEITZ, A. M., 1993, Anatomical sequence and morphometric analysis during somatic embryogenesis on cultured cotyledon explants of Camellia japonica L.. Ann. Bot., 71: 359-404.

CANHOTO, J. M. \& CRUZ, G. S., 1996, Histodifferentiation of somatic embryos in cotyledons of pineapple guava (Feijoa sellowiana Berg.), Protoplasma, 191: 35-45.

CANHOTO, J. M., LOPES, M. L. \& CRUZ, G. S., 1999, Somatic embryogenesis and plant regeneration in myrtle (Myrtaceae), Plant Cell, Tissue and Organ Cult., 57: 13-21.

CHRISTIANSON, M. L. \& WARNICK, D. A., 1988, Organogenesis in vitro as a developmental process, HortSci., 23: 515-519.

DANIEL, O., COSTA, L. G. S. \& OHASHI, S. T., 1994, Morototó - Didymopanax morototoni (Aubl.) Dene et Planch. Belem, EMBRAPA CPATU, 15.

DE JONG, A. J., SCHMIDT, E. D. L. \& VRIES, S. C., 1993, Early events in higher-plant embryogenesis, Plant Molecular Biology, 22: 367-377. 
EVANS, D. F., FLICK, C. E. \& JANSEN, R. R., 1981, Disease resistance incorporation into sexually incompatible somatic hibryds of the genus Nicotina. Science, 213: 907-909.

FAURE, O., AARROUF, J. \& NOUGARÈDE, A., 1996, Ontogenesis, differentation and precocius germination in anther-derived somatic embryos of grapevine (Vitis vinifera L.) embryonic organogenesis, Ann. Bot., 78: 29-37.

FRANCO, E. T. H. \& FERREIRA, A. G., 2002, Pregermination treatments in Didymopanax morototoni (Aubl.) Dcne. et Planch. Seeds, Ciencia Florestal, 12: 1-10.

GABRIEL, B. L., 1984, Biological Electron Microscopy, Van Nostand, New York, pp. 1-264

GRATTAPAGLIA, D. \& MACHADO, M. A., 1999, Micropropagação, pp. 183-260. In: A. C. Torres, L. S. Caldas \& J. A. Buso (Eds.) Tecnicas e aplicações da biologia celular e molecular em plantas. EMBRAPA/ CNPH, Brasilia.

GUERRA, M. P. \& HANDRO, W., 1998, Somatic embryogenesis and plantlet regeneration in different organs of Euterpe edulis Mart. (Palmae): control and structural features, J. Plant. Res., 111: 65-71.

HACCIUS, B., 1978, Question of unicellular origin of non-zygotic embryos in callus cultures, Phytomorph., 28: 74-81.

HAMAMA, L., BAAZIZ, M. \& LETOUZE R., 2001, Somatic embryogenesis and plant regeneration from leaf tissue of jojoba, Plant Cell, Tissue and Organ Culture 65: 109-113.

HARRY, I. J., THORPE, T. A., 1991, Somatic embryogenesis and plant regeneration from mature zygotic embryos of red spruce, Bot. Gaz., 152: 446-452.

HDIDER C. \& DESJARDINS Y., 1994, Effects of sucrose on photosynthesis and phosphoenol pyruvate activity of in vitro cultured strawberry plantlets. Plant Cell, Tissue and Organ Culture, 1(36): 27-33.

JIMENEZ, V. M., 2001, Regulation of in vitro somatic embryogenesis with emphasis on the role of endogenous hormones. R. Bras. Fisiol. Veg., 13: 196-223.

LITZ, R. E. \& JARRET, R. L., 1991, Regeneration de plantas em el cultivo de tecidos: embriogenesis somatica y organogenesis. pp. 143-172. In: W. M. Roca \& L. A. Mroginski (Eds.) Cultivo de tecidos en la agricultura. Colombia, CIAT.

LLOYD, G. \& MCCOWN, B., 1980, Commercially feasible micropropagation of mountain laurel, Kalmia latifolia, by use of shoot tip culture, Proc.Int.Plant Prop.Soc., 30: 421-427.

MANTOVANI, N. C., FRANCO, E. T. H., GUERRA, M. P. \& HOPPE, J., 1999, Micropropagação de caixeta Didymopanax morototoni (Aubl.) Dcne et Planch., Ciencia Florestal, 10: 15-33.

MANTOVANI, N. C. \& FRANCO, E. T. H., 2000, Respostas morfogeneticas em explantes foliares de Didymopanax morototoni (Aubl.) Dcne. et Planch. Rev. bras. Agrociencia, 6: 269-272.

MATHUR, A., MATHUR, K. A. \& GANGUAR, A., 2001, In vitro plantlet regeneration in Panax sikkimensis, Plant Medica, 67: 181-183.
MURALIDHARAN, E. M. \& MASCARENHAS, A. F., 1995, Somatic embryogenesis in Eucaliptus pp. 24-40. In: S. M. Jain, Gupta, P. K. \& R. J. Newton, (Eds) Somatic embryogenesis in woody plants: angiosperm. Dordrecht, Kluwer Academic.

O'BRIEN, T. P. \& MCCULLY, M. E., 1981, The Study of Plant Structure Principles and Selected Methods, Melbourne, Termacorphi, 345p.

PIJUT, P. M., 1993, Somatic embryogenesis in butternut (Juglans cinerea) Can. J. For. Research, 23:835-838.

PUIGDERROJOLS, P., MIR, G. \& MOLINAS, M., 2001, Ultrastructure of early secondary embryogenesis by multicellular and unicellular pathways in cork oak (Quercus suber L.), Ann. Bot., 87: 179-189.

RAEMAKERS, C. J. J. M., JACOBSEN, E. \&. VISSER, R. G. F., 1995, Secondary somatic embryogenesis and applications in plant breeding, Euphytica, 81: 93-107.

ROUT, G. R. \& DAS, P., 1994, Somatic embryogenesis in Simarouba glauca. Plant Cell, Tissue Cult., 37: 79-81.

SHARP, W. R., SONDAHL, M. R, CALDAS, L. S. \& MARAFFA, S. B., 1980, The physiology of in vitro assexual embryogenesis. Hortic. Rev., 2: 268-310.

SHIBLI-RIDA, S., SHATNAWI, M. \& AL-JUBOORY, K. H., 2001, Somatic embryogenesis and plant recovery from callus of "Nabali"olive (Olea europea L.) Sci. Hort. 88: $243-256$

TISSERAT, B., ESAN, E. B. \& MURASHIGE, T., 1979, Somatic embryogenesis in angiosperms, Hortic. Rev., 1: $1-78$.

TREWAVAS, A., 1991, How do plant substances work? Plant, Cell and Envirom., 14: 1-12.

VASIL, I. K., 1982, Somatic embryogenesis and plant regeneration in cereal and grasses, pp. 101-103. In: A. Fujiwara, Plant Tissue Culture. Maruzen, Tokyo.

VERDEIL, J. L., HOCHER, V., HUET, C., GROSDEMANGE, F., ESCOUTE, J., FERRIERE, N. \& NICOLE, M., 2001, Ultrastructural changes.in coconut cell associated with the acquisition of embryogenic competence. Ann. Bot., 88: 9-18.

VON ARNOLD, S. \& ERIKSSON, T., 1980, In vitro studies of adventitious shoot formation in Pinus contorta, Can. J. Bot., 59: 870-874.

WILLIAMS, E. G. \& MAHESWARAN, G., 1986, Somatic embryogenesis: factors influencing coordinated behaviour of cells as an embryogenic group, Ann. Bot., 57: 443-462.

ZEGZOUTI, R., ARNOULD, M.F.. \& FAVRE, J.M., 2001, Histological investigation of the multiplication step in secondary somatic embryogenesis of Quercus robur L., Annals of Forest Sci., 58: 681-690. 